\title{
4
}

\section{Liberalisation of Trade in Agricultural Products}

\section{Introduction}

Securing further liberalisation of trade in goods and trade in services is one of the most important objectives of the negotiations in the Doha Round. This chapter describes the assistance provided to the members of the Geneva Group of Commonwealth Developing Countries on the approach they could adopt in the negotiations on agricultural products.

The WTO's definition of 'agricultural products' differs slightly from that of the World Customs Organization (WCO), the only intergovernmental organisation exclusively focused on customs matters. Under the WCO Harmonized System Classification, products falling under chapters 1 to 24 are treated as agricultural products and those falling under chapters 25 to 99 are treated as industrial products. This definition is used in a slightly modified way in WTO work. For instance, in WTO work fish and fish products are treated as non-agricultural or industrial products but in the WCO classification they are treated as agricultural products under chapters 1 to 24 . Further, products such as essential oils, hides and skins, raw fur skins, and silk and silk waste fall under chapters 25 to 99 in the WCO clarification and are therefore treated as industrial products while they are treated as agricultural products in WTO work.

\section{Pre-Uruguay Round: Legal Situation Regarding Application of GATT Rules}

Prior to the conclusion of the Uruguay Round and the establishment of WTO in 1995, the rules of GATT applicable to agricultural products were much weaker than those applicable to industrial products. For instance, the rule prohibiting countries from using export subsidies was applied broadly to non-agricultural products and not to agricultural products. In practice also, most countries did not abide by the rule against the use of quantitative restrictions and other similar measures in the agricultural sector. The US was able to apply quantitative restrictions to imports of agricultural products because it had obtained a waiver from its GATT obligations but the application of such restrictions by other countries constituted a breach of their obligations. Some of these countries, most notably those belonging to the EU, 
adopted systems such as variable levies. Under this system the rate of tariff payable on imported agricultural products was determined on a transaction-by-transaction basis, taking into account the differences between the higher guaranteed price payable to domestic farmers and the lower price of the imported products. These variable customs tariffs (or 'levies' as they were called) insulated the domestic market from foreign competition and as such had in practice the same (or even more) restrictive effect on trade as quantitative restrictions. In addition, in order to ensure reasonable level of income to the farming community and parity between the income levels of farmers and industrial workers, a number of developed countries had adopted domestic support systems involving heavy use of subsidies. These subsidies often encouraged farmers to increase production even though the cost of production was much higher than in countries that were efficient producers of agricultural products. The result was that products in excess of domestic requirements could be sold in international markets only by granting export subsidies.

\section{Reform programme}

The Agreement on Agriculture negotiated in the Uruguay Round, took the first major step towards ensuring that countries applied the basic principles of GATT to agricultural products. The agreement adopted a reform programme covering the measures applied by countries at their borders (e.g. tariffs and quantitative restrictions) and in regard to the use of subsidies (both export and domestic).

The programme recognised that the reform process would have to be gradual. The new and strengthened rules and the measures taken for further liberalisation of trade would have to take into account the special features of trade in agriculture as well as non-trade concerns, including those relating to food security and environmental protection. It further provided that the programme should be reviewed and negotiations for further liberalisation of trade and improvements in the rules should commence within a five-year period (i.e. before 2001).

\section{Tariffication}

One of the main achievements of the reform programme adopted under the Agreement on Agriculture was that countries were required to eliminate any quantitative restrictions or such systems as variable levies that they had applied in the agricultural sector. In order to guard against a sudden reduction in the level of protection enjoyed by domestic producers, the rules provided that the 'tariff equivalent' of such restrictive measures should be calculated and added to the tariff applicable to the concerned products. This process has come to be known as tariffication.

Products on which duties were tariffied included mainly temperate zone products, such as cereals and flour, meat and dairy products and such products as fresh fruits and vegetables, and vegetable oils. The countries were required to reduce their tariffs, 
including the new tariffed rates, on all agricultural products. The developed countries reduced their tariffs at an average rate of 36 per cent while developing countries reduced them by 24 per cent.

The other feature of the reform programme was that all countries, including developing and least-developed countries were required to bind all of their tariffs against further increases. However, they were given the flexibility to give bindings at ceiling rates, which could be higher than their applied rates or those resulting from reductions agreed in the negotiations.

\section{Special agricultural safeguards}

Countries, mainly the developed ones that were eliminating quantitative restrictions and systems of variable levies, were apprehensive that in certain sectors the resulting increase in imports may adversely affect domestic production (despite being permitted to apply higher rates of tariffs through the tariffication process). In order to meet these concerns the agreement provided for a special agricultural safeguard mechanism. This mechanism allowed additional duties to be levied on products to which tariffed rates applied, if the volume of imports increased over and above a specified percentage or prices declined below the average level of prices in the preceding threeyear period.

\section{Export and domestic support subsidies}

In addition to improving the discipline applicable to the measures countries apply at the border, the reform programme took steps to improve the discipline applicable to the use of subsidies in the agricultural sector.

Export subsidies (i.e. subsidies that are linked to exports) are considered to be most distorting from the point of view of trade. It was for this reason that in 1960 a Decision was adopted to prohibit the use of export subsidies on industrial products. These rules, however, did not apply to agricultural products. The Agreement on Agriculture aimed at extending these rules to agricultural products but it recognised that farmers in some of the major developed countries were heavily dependent on such subsidies for sale of their agricultural products in international markets. Therefore, it would not be possible for governments of these countries to agree that the use of export subsidies on agricultural products should be prohibited. The approach adopted required the countries that were granting such subsidies to reduce them by giving reduction commitments and listing these in their schedules of commitments.

All subsidies other than export subsidies are treated under the agreement as domestic subsidies. Such subsidies are further divided into two categories, those that are trade distorting and those that are not. The Agreement categorises the various subsidies by the colours green, blue and amber. 
Non-trade distorting subsidies are either categorised as green or blue box subsidies. All those that have 'no or most minimal, trade distorting effects on production' and do not have the effect of providing price support to production are known as green box subsidies and are exempt from reduction commitments. Such subsidies include among others, those granted for research, pest control, marketing and promotion services, governmental participation in income insurance and income safety programmes, structural adjustment programmes, regional assistance programmes, environmental programmes and payments for natural disasters.

During the last phase of the negotiations, it was also agreed that 'direct payments' to farmers who participate in 'production limiting or reduction programmes' should also be treated as non-trade distorting and exempted from reduction commitments. These subsidies, which were granted at that time primarily by the EU and the US, have come to be known as blue box subsidies.

All subsidies other than those categorised as green and blue are treated as trade distorting subsidies and called amber subsidies. The agreement required countries to calculate the total amount of such subsidies granted by them in the base period from 1985 to 1986. The legal term used to designate the total amount of such subsidies paid by a country is 'aggregate measure of support (AMS)'. In arriving at AMS on this basis, countries were permitted to treat product specific subsidies that were less than 5 per cent of the value of that product as de minimus and exclude them from calculation. Likewise, non-product specific domestic subsidies could be excluded from the calculation, if they did not exceed 5 per cent of the value of production. For developing countries, the de minimus levels for both product and non-product subsidies were fixed at 10 per cent. The agreement imposed an obligation on developed countries to list the amount of AMS in their GATT schedules and to reduce it by specified percentages.

The developed countries were required to reduce their AMS calculated on the above basis by 20 per cent over a period of six years from 1 January 1995. The developing countries were required to reduce their AMS at a lower rate that was two-thirds of the percentage at which developed countries were required to reduce over a period of 10 years. The time provided for reducing subsidies has now expired and the countries that have reduced the AMS are under an obligation to ensure they do not allow their trade distorting subsidies to exceed the resulting reduced level.

\section{Operation of the Reform Programme}

What has been the experience in implementing the reform programme?

\section{Tariffs of developed countries}

Even after the reductions made in the Uruguay Round, the rates of tariffs applicable to agricultural products in developed countries remained substantially high as 
compared to those they applied to industrial products. This was largely due to two factors. First, in the rounds of negotiations held prior to the Uruguay Round a number of these countries had excluded agricultural products from tariff reductions. Second, in the Uruguay Round while adding the tariff equivalence of the protection provided by the quantitative restrictions that were being removed to the rate of tariffs, countries had deliberately inflated the equivalence. Since almost all developed countries had resorted to this practice, there was a 'gentleman's agreement' among them not to challenge the calculation of tariff equivalence made by the others. As a result of this process of 'dirty clarification,' for a number of products the base rate used for reduction remained high.

The result was that apart from a few tropical products like tea, coffee and cocoa (products predominantly produced in developing countries on which duties were removed), peak tariffs in excess of 12 per cent continue to be applied on a large number of products such as cereals and flour, fresh fruits and vegetables, vegetable oils, meat, fish and dairy products. Many of these products are also of export interest to developing countries. UNCTAD (1997) estimates that over 10 per cent of 4,000 or so tariff lines in the schedules of each of the developed countries (Canada, EU members, Japan and US) continue to face such tariffs. Further, 15 per cent of the peak tariffs in Canada, 20 per cent of those in the US, 20 per cent of those in the EU and 30 per cent of those in Japan were above the level of 30 per cent. In addition, excessively high rates exceeding 70 per cent were applicable to products on which duties had been tariffed (UNCTAD 1997, p. 134).

\section{Increasing use of subsidies}

The Agreement on Agriculture had envisaged that putting a ceiling on the use of domestic trade distorting subsidies and export subsidies, and requiring countries to reduce them by agreed percentages, would curtail the use of subsides in the agricultural sector. But four years after the implementation of the Uruguay Round commitments relating to subsides, while most of the countries had reduced their trade distorting subsidies according to their stated commitments, they were compensating farmers for the reduction by increasing permissible subsidies listed in the green and blue boxes. Thus, the overall level of domestic support had increased instead of declining.

Export subsidies also increased over the commitment levels as some of the countries, while making reductions according to commitments, were replacing them with export credit guarantee schemes or market promotion programmes. The discipline of the agreement did not apply to such measures; it only emphasised the need to develop international discipline in this area. The rise in the use of both domestic and export subsidies by major developed countries had frustrated one of the basic objectives of the Agreement on Agriculture, that of bringing under control the use of trade distorting subsidies, both domestic and export. 


\section{The Negotiating Approach}

Taking into account the main features of the reform programme embodied in the Agreement on Agriculture and the experience of its operation, as described above, the Adviser put forth suggestions on the general approach that could be adopted in the negotiations on the liberalisation of trade and improvement of rules governing trade in agriculture. The suggestions were set out in background papers, particularly the Working Paper on Agricultural Products, prepared by the Adviser for consideration by the members of the Group. Following are the suggestions made in regard to the main elements (Rege 2001).

\section{Tariffs}

\section{Reductions by developed countries}

The aim of the negotiations in this area should be to secure from developed countries further significant reductions in tariffs, particularly of peak tariffs. Further reductions in tariffs on final processed products and on raw materials used in further processing should be made in such a way as to eliminate tariff escalations and where this is not possible, to reduce them. Towards this end the modalities for negotiations should provide that they could reduce their tariffs either on the basis of an across-the-board cut in tariffs using a formula, or by 'request' and other procedures.

With respect to making reductions on the basis of a formula, the Swiss formula (adopted in the Tokyo Round) that resulted in deeper cuts being made in higher duties, should be given consideration. The ground rules for negotiations should also provide for developing countries to make requests to developed countries for deeper cuts than those resulting from the application of the tariff cutting formula, on products of specific interest to them. It should also be open to countries that enjoy preferential access to the markets of developed countries to request that a limited number of products for which 'the preferential margins provide meaningful advantage' should be exempted from tariff reductions. Alternatively, cuts in most-favoured-nation tariffs on such products should be made at a rate that is 'lesser' than that resulting from the formula. The other alternative would be to provide for a longer time (say 15 years) for phased reductions of duties applicable to such products.

\section{Reductions by developing countries}

In deciding on the approach that could be adopted on the extent to which developing countries should reduce their tariffs, the working paper emphasised that it would be essential to take into account the differences in the way countries undertake production in the agriculture sector. Production in most of the countries that are efficient exporters of agricultural products (Australia, Canada, New Zealand and the US among developed countries and Argentina, Brazil and Uruguay among developing 
countries) is undertaken on large farms consisting of thousands of acres, and in many cases owned by big corporations. The huge size of the farms enables the use of the most modern mechanised and scientific methods of production. The resulting low cost of production enables them to market their products at relatively low prices in foreign markets. On the other hand in most of the developing countries, particularly in the Commonwealth countries belonging to Africa, Asia and the Caribbean regions, production of food crops and of animal and dairy products is undertaken on small farms mostly for consumption in the domestic markets and only a small proportion is exported. A high proportion of production in these countries originates from 'subsistence farming'. As such the bulk of food and animal products produced are consumed by the poor farmers for their sustenance and the remaining small proportion is sold in the neighbouring domestic market to obtain in return the requirements of clothing and other essential articles. As a result of the small size of farms and the inability of poor farmers to use new technologies and the inputs like fertiliser and insecticide required for efficient production, costs tend to be high.

The past experience of these countries with regard to the liberalisation measures imposed on them under the IMF's structural adjustment programmes has shown that increased imports at low prices gradually displaces domestic production causing many poor small farmers to lose their main source of income. In other words, reductions in tariffs and the removal of other restrictions on food, fresh fruits and vegetables, poultry and dairy products, pose serious problems for small farmers in these countries, particularly the least developed and those with small economies. These problems are further compounded by the fact that a large proportion of the population of these countries (in some cases as high as 60 per cent) is dependent on agriculture as even after liberalisation of trade and relaxation of restrictions on investment, no new industries are being created so the farmers and agricultural workers affected by increased imports are not able to find alternative employment.

In the light of this experience, more and more questions are being raised about an economic rationale for trade policy with such an emphasis on the pursuit of open and liberal trade policies. Academics and policy-makers are increasingly challenging the thesis that the pursuit of such policies automatically leads to economic growth, both on methodological and theoretical grounds. Many now recognise that, at least in the field of agriculture, exposure of producers to unbridled foreign competition could only lead to displacement of domestic production by imports, resulting in high economic and social costs to the local population. This was well brought out by the recent experience of some of the developing countries, particularly in Africa, where the increased imports of cheap food products appeared to be increasingly displacing domestic production.

Given this situation, the working paper suggested that the extent to which developing countries should reduce tariffs and the coverage of products would have to be determined by them, taking into account their stage of development. As provided 
in the Doha Declaration, in trade negotiations these countries are required to make contributions on reducing tariffs that are based on the principle of 'less than fall reciprocity' and, further, are not inconsistent with their trade, financial and development needs. For the achievements of these negotiating objectives, the modalities that may be adopted for negotiations would have to provide for two basic positions. First, irrespective of whether developing countries are required to reduce tariffs on the basis of a formula or on request and other procedures, they should be required to make reductions at rates that are lower than the rates at which reduction on a percentage basis would be made by developed countries. Second, these countries should have a right to exclude from reductions, or make less than average percentage reductions on, products on which they consider existing protection must be maintained in order to ensure food security and livelihood to poor farmers living at subsistence level, and to promote rural development by establishing agro-based industries.

\section{Special safeguard measures}

The working paper further pointed out that some of the developing countries that had undertaken measures for liberalisation of trade, either on a unilateral basis or under structural adjustment programmes sponsored by the IMF or the World Bank, were finding that the existing levels of protection for some of their products were inadequate. Because of this, producers in these countries were finding it difficult to compete with low cost imports originating in countries where costs of production tended to be lower. The worst affected sectors included vegetable oils, poultry, and milk and dairy products. In light of this situation, it would be necessary to include in the WTO legal framework provisions permitting developing countries to apply special safeguards to restrict imports for a temporary period. Any such provisions would be different from the 'special agricultural safeguards' clause included in the Agreement on Agriculture in two respects. First, it would stipulate that the measures could be applied to all products not merely those on which rates were determined in the Uruguay Round through the tariffication process. Second the right to use such safeguards would be available only to developing countries and should be based on the following principles:

- Developing countries could apply such measures to imports of agricultural products where a product is being imported in increased quantities by (x) percentage of the average level of imports reached in the previous three years, or where the price at which the product is entering the customs territory has fallen below the 'trigger price' calculated on the basis of average prices of imports for the previous three years.

- In all cases where the measures taken conform to the above-mentioned criteria, it shall be assumed that increases in the level of imports were causing or threatening injury to domestic production. 
- Special safeguard measures can take the form of additional duty or quantitative restrictions on imports, but quantitative restrictions should only be applied only in exceptional cases, where it was considered that the application of increased tariffs might not result in significant reductions in imports.

- Any country taking the decision to apply special safeguard measures shall notify the WTO Secretariat, immediately after the decision is taken.

\section{Domestic support and export subsidies}

Taking into account the problems and issues arising in the implementation of the Agreement on Agriculture rules on the use of domestic and export subsidies, the working paper prepared by the Adviser made the following suggestions on the approach that members of the Group could consider adopting in further negotiations:

\section{Green and blue box subsidies}

It has been possible for developed countries to circumvent their commitments under the Agreement to reduce trade-distorting subsidies by substituting them with subsidies permitted under green and blue boxes. In the case of permissible green box subsidies, it would be desirable to examine and adopt a suitable discipline to prevent their use as a substitution for trade distorting subsidies. As regards blue box subsidies, since they were used mainly by the EU and the US and in practice are not necessarily trade neutral, it would be desirable for developing countries to support proposals for their abolition as a separate category and for their inclusion in the aggregate measures of support.

\section{Aggregate measures of support}

In the Uruguay Round countries using such subsidies had agreed to a ceiling on their use and to further reduce them by 20 per cent over a period of eight years, that is, by 2003. Against this background, the negotiating approach could be to secure deeper cuts in the reduced permissible levels reached by 2003 , with a view to securing elimination of the use of such trade distorting subsidies by all countries by a fixed target date.

\section{Export subsidies}

Since export subsidies distort conditions of competition and of trade, it would be in the interest of developing countries to negotiate for all countries to prohibit the use of them. Simultaneously, efforts should be made to develop a discipline that should apply to export credit, export credit guarantee and insurance programmes. 


\section{Tentative Agreements on the Modalities}

The background information on the implementation of the reform programme adopted under the Agreement on Agriculture and the suggested negotiating approach set out in the working and other papers, provided members of the Group with a sound and informed basis for deciding on the strategy to adopt in the negotiations. A brief overview of the 'tentative' agreements reached in mid-2010 on the modalities that could be adopted for negotiations in the area of agriculture is provided below. It should be emphasised that the numbers indicated for percentage reduction in tariffs and subsidies or for the application of increased duties under special safeguard measures are only tentative; they indicate an assessment by the Chairman of the Negotiating Group on the basis of which agreement may be reached when final negotiations take place during the concluding phase of the negotiations (WTO 2008a, 2008b).

\section{Tariffs}

Developed countries should reduce tariffs on the basis of the 'tiered formula' (Table 2), which provides for greater percentage reductions being made in higher rates of tariffs.

Table 2: The tiered formula

\begin{tabular}{cc}
\hline Tariff range & Percentage cut \\
\hline 0 to 20 & $50 \%$ \\
20 to 50 & $57 \%$ \\
50 to 75 & $64 \%$ \\
75 and above & $70 \%$ \\
\hline
\end{tabular}

The tariff ranges listed above have been slightly modified to take into account the tariff structure of the developing countries but broadly speaking these countries are expected to make two thirds of the cut that would be made by the developed countries, in each tariff range.

The maximum average cut developed countries are expected to make by using the tiered formula shall be 54 per cent while the maximum average level of cuts that developing countries must achieve is 36 per cent. In cases where the application of the formula results in an overall average tariff cut of more than 36 per cent the developing country concerned shall have the flexibility to decrease reductions across the bands, to keep within the average level.

Developed countries would reduce their tariffs over a period of six years, developing countries over a period of ten years. 


\section{Least-developed countries, small vulnerable economies}

In the initial phase of the negotiations the developed countries had taken the position that apart from the least-developed countries all developing countries, whatever may be the stage of development reached by them, must make tariff reductions on the basis of the tiered formula. But as the negotiations proceeded they started showing a willingness to consider sympathetically the pleas from countries with small and vulnerable economies or at the middle level of development, that they should not be required to make tariff cuts on the basis of the formula. This change in position by the developed countries could be attributed to two factors.

First, these small and vulnerable countries - using arguments based on the analysis contained in the working paper prepared under the project and similar papers prepared by UNCTAD as well as in some of the empirical studies undertaken by academic institutions - were able to make a case for more favourable treatment in reduction of tariffs than that extended to other developing countries. Gradually, some of the developed country negotiators started realising that it would not be appropriate to insist that the principle of 'one size fits all' should apply to the liberalisation measures to be taken by developing countries. These negotiators were further influenced by pressures from non-governmental organisations in their countries, and in some cases from the members of their own parliaments. The NGOs and MPs considered that it would not be in the trade and development interests of small and vulnerable countries, or those in the middle stage of development, to liberalise their trade on the same basis as emerging countries that were rapidly developing and had already reached a relatively high stage of development.

Second, in tactical terms the negotiators from some of the developed countries considered that by conceding to the demands of small and vulnerable economies and of countries at the middle stage of development, they would be able to isolate the emerging economies, which in their view provided the main potential markets for their exports. They could thus confine the discussions on levels of percentage cuts and on the exclusions of products from tariffs reductions (so called special products) to be settled in negotiations with the emerging countries.

The result was that criteria for identifying the small and vulnerable economies was elaborated in such a way that it could cover a large number of countries which are at lower or middle stage of development. For the purpose of negotiations on agricultural products, the criteria adopted provides that the term 'small and vulnerable economies' would apply to countries with the following average shares in world trade in the period from 1999 to 2004: merchandise of no more than 0.16 per cent; nonagricultural products of no more than 0.1 per cent; and agricultural products of no more than 0.4 per cent.

On the basis of the above criteria 45 countries have been identified as small and vulnerable economies for the purpose of negotiations on agricultural products (Box 7). 


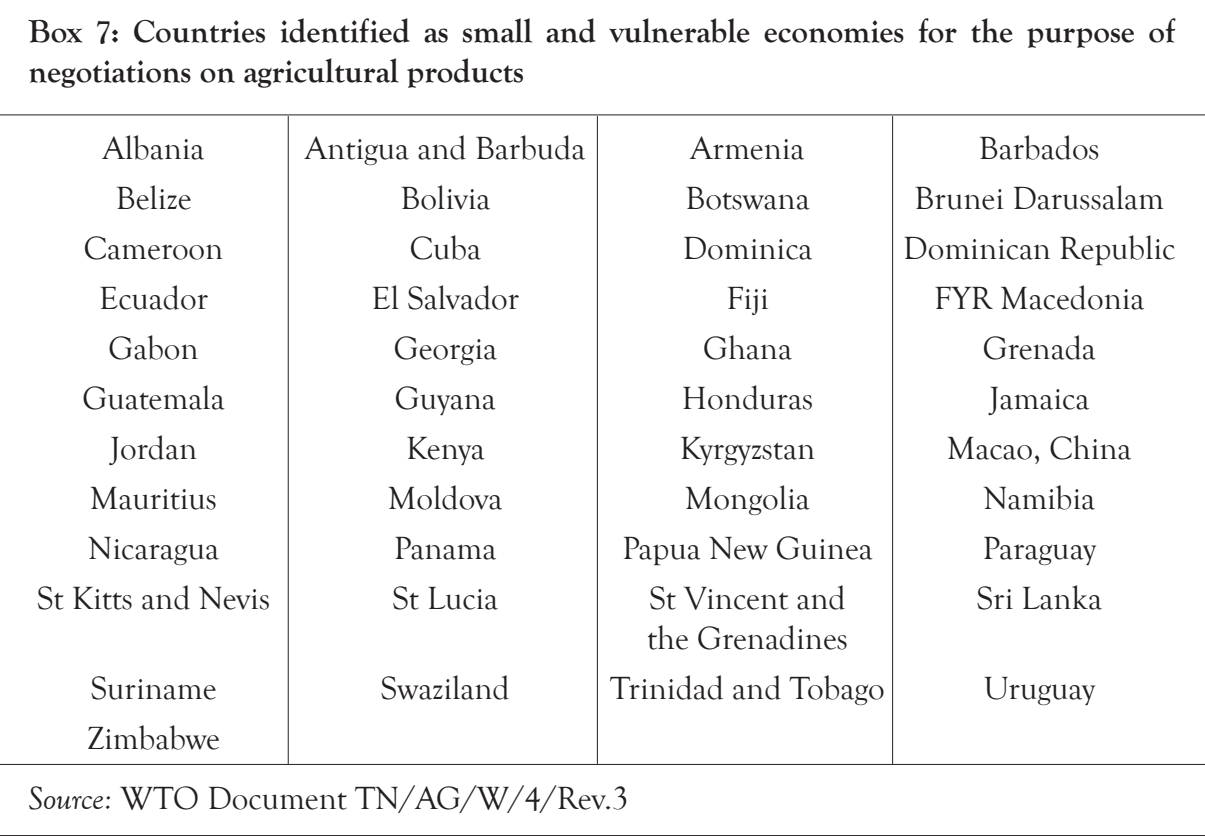

They include small-island states of the Caribbean and Pacific regions, but also countries belonging to the African and South American regions as well as some countries that are transitional economies.

It is important to note that this categorisation of small and vulnerable economies is only intended for use in the modalities for negotiations on agricultural products during the present round and does 'not constitute the creation of a new category of WTO members'.

The countries identified as small and vulnerable economies have been given two options. They can either apply the tiered formula, or they can simply make an overall average cut of 24 per cent and designate as many products as they wish as special products (provided the overall average percentage cut is reached). The least-developed countries are not required to make any reductions in tariffs on agricultural products during this round.

\section{Product exclusion: sensitive products}

At broad policy level, developed countries as a group were lending support to the proposals for deeper cuts being made in tariffs applicable in the agricultural sector, across the board and without any exception. However, as the negotiations proceeded some of them began demanding that they should be also entitled to exclude certain products from tariff reductions, particularly those that were import sensitive or where a 
continued level of production was considered necessary for environmental and other reasons. As a result of the pressure exerted by them it is now tentatively agreed that developed countries may deviate from tariff reduction resulting from the formula and make small reductions by designating 4 per cent of their tariff lines as sensitive products. Developing countries have a right to designate up to one-third more of tariff lines as sensitive products.

\section{Special and differential treatment to developing countries}

\section{Special products}

The right to exclude sensitive products would be available to both developed and developing countries. The latter countries would have a further right to 'self designate' 12 per cent of tariff lines as special products by using the indicators that have been elaborated. No cuts may be made on 5 per cent of such tariff lines. They would however have to ensure the average cut on tariff lines that are treated as special products shall be no less than 10 to 14 per cent.

\section{Special safeguard measures}

Developing countries would have a further right to apply special safeguard measures where the volume of imports exceeds average imports by a specified percentage in the preceding three years, or if the import price of the shipment falls below a trigger price equal to 85 per cent of average monthly MFN-sourced price for that product in the most recent three-year period. In cases where safeguard measures are applied on the basis of a volume trigger, the rate of additional duty that could be imposed is determined on the basis shown in Table 3 .

Table 3: Rules governing imposition of duties on the basis of volume trigger

\begin{tabular}{cl}
\hline Increase in the volume of imports & Additional duty that can be levied \\
\hline $110 \%$ & $25 \%$ of the current bound rate or \\
& 25 percentage points, whichever is higher. \\
$115 \%$ & $40 \%$ of the current bound tariff or \\
& 40 percentage points, whichever is higher. \\
$135 \%$ & $50 \%$ of the current bound tariff or \\
& 50 percentage points, whichever is higher.
\end{tabular}

\section{Domestic subsidies}

\section{Cuts in overall trade distorting subsidies}

The proposed modalities provide that in addition to amber subsidies, blue box subsidies, which are not at present treated as trade distorting, should also be subjected 
to cuts. Countries would also be required to reduce the present levels of de minimus subsidies, which they are at present allowed to exclude from the calculation of the agreed measures of support. For this purpose a new concept of 'overall trade distorting subsidies' (OTDS) has been adopted. To arrive at the OTDS the permissible amount of AMS specified in the schedule is added to the higher average level of blue box subsidies granted by the country during the period 1995 to 2000 . The developed countries are expected to include a further 10 per cent of the average total value of agricultural production in the period from 1995 to 2000. This amount reflects 5 per cent of the average total value of production that countries are allowed to exclude from AMS for product specific subsidies. In the case of developing countries, 10 per cent of the average production is to be added to the OTS, as the de minimus subsidies that could be excluded in calculating AMS are 10 per cent each for product and nonproduct specific subsidies.

Countries would be required to cut the OTDS calculated on the above basis using a formula that would provide for greater cuts being made by countries with the highest OTDS. At time of writing the EU has the highest level of OTDS so if this formula were accepted the EU would make 80 per cent cuts. By the same token, the US and Japan would cut their OTDS by 70 per cent and other countries by 55 per cent. Developed countries would be required to make these cuts over a period of five years and developing countries over 10 years.

\section{Cuts in the AMS}

Within the overall cuts provision has been made for reductions in the aggregate measures of support (AMS) as follows:

- Where the final bound total AMS is greater than US\$40 billion the reduction shall be 70 per cent $(E U)$;

- Where the final bound total AMS is greater than US\$15 billion and less than US $\$ 40$ billion the reduction shall be 60 per cent (USA and Japan);

- Where the final bound total AMS is less than US\$15 billion the rate of reduction shall be 45 per cent (other countries).

\section{Cuts in de minimus levels}

Developed countries would reduce the de minimus level of both product and nonproduct subsidies that can be excluded from the escalation of AMS (to be used for calculation based on the above) from 5 per cent to 2.5 per cent. Developing countries, which are allowed to treat 10 per cent of such subsidies as de minimus, would be required to cut them by two thirds of the rate at which the developed countries would be reducing their de minimus levels. In this case, since the de minimus level for product and non-product subsidies is 10 per cent, the de minimus level after reduction 
would be 6.7 per cent. However, the developing countries would not be required to make any cuts in the de minimus in subsidies that are granted mainly to poor farmers living at subsistence level.

\section{Cuts in cotton subsidies}

In order to help developing countries that are heavily dependent on the production and export of cotton, and that are losing their share of the international market as a result of subsidies granted by developed countries, modalities provide that these countries should make reductions in such subsidies on the basis of a formula that would result in cuts at rates higher than those on which subsidies would be reduced on other agricultural products.

\section{Cuts in blue box subsidies}

The definition of 'blue box' subsidies would be broadened to cover programmes that do not require farmers to cut production, in addition to programmes that require them to limit production. The use of these broadened subsidies by developed countries would be limited to 2.5 per cent of the value of the total average level of production in the period 1995 to 2000 and in the case of developing countries this limit would be 5 per cent. There would also be caps on the use of such subsidies per product.

\section{Export subsidies}

There is a general consensus that the countries granting such subsidies should eliminate them by the end of 2013, with at least half of them eliminated by 2010. Revised rules have been adopted to bring export credits, and export credit guarantee and insurance programmes under greater discipline.

\section{References}

Rege, V. 1999. Business Guide to the World Trading System. London: Commonwealth Secretariat and International Trade Centre.

-2001. Trade in Agriculture. Working Paper 1 of the Geneva Group of Commonwealth Developing Countries. London: Commonwealth Secretariat. February.

UNCTAD. 1997. Trade and Development Board Report, 1997. Geneva: UNCTAD.

WTO. 2001. Ministerial Declaration Launching the Doha Development Round of Negotiations. WT/MINCOM/Dec/1. 14 November.

— 2005. Hong Kong Ministerial Declaration. WT/MIN(05)/DEC 18 December. 
